\title{
Peremajaan Lahan Terdampak Tsunami Menjadi Ruang Terbuka Hijau Melalui Pendekatan Perencanaan Kolaboratif di Kota Banda Aceh (Studi Kasus Hutan Kota BNI Tibang dan Taman Kota BNI Trembesi)
}

\author{
Hafi Munirwan ${ }^{1}$, Marsista Buana Putri ${ }^{2}$, Fran Sinatra ${ }^{3}$ \\ ${ }^{1,2,3}$ Program Studi Perencanaan Wilayah dan Kota, Institut Teknologi Sumatera \\ Correspondence email: hafi.munirwan@pwk.itera.ac.id
}

\begin{abstract}
Abstrak. Ruang terbuka hijau (RTH) merupakan komponen penting yang berfungsi sebagai penyeimbang ekosistem kota. Keberadaan RTH semakin terdesak akibat pesatnya laju urbanisasi di Indonesia yang berdampak terhadap semakin sulitnya penyediaan RTH di kawasan perkotaan. Salah satu lahan yang dapat dioptimalkan dan dimanfaatkan menjadi RTH adalah lahanlahan yang telah mengalami degradasi maupun lahan terlantar yang dapat disebabkan oleh berbagai faktor, salah satunya adalah bencana alam. Hutan Kota BNI Tibang dan Taman Kota BNI Trembesi merupakan RTH yang dikembangkan pada lahan terlantar yang terdampak bencana Tsunami yang menimpa Aceh pada 2004. Penelitian ini bertujuan untuk mengkaji kolaborasi yang dilakukan antara stakeholder pemerintah dan non-pemerintah dalam peremajaan lahan terdampak Tsunami menjadi RTH yang terdiri dari Hutan Kota BNI Tibang dan Taman Kota BNI. Hasil dari penelitian menunjukkan bahwa peremajaan lahan terdampak Tsunami menjadi RTH telah memberikan kontribusi RTH masing-masing seluas 6,75 Ha dan 2,59 Ha. Disamping itu, hasil penelitian turut menunjukkan keterlibatan sejumlah stakeholder non-pemerintah yang terdiri dari lembaga swadaya masyarakat (LSM), swasta, dan masyarakat dalam tahap inisiasi, implementasi dan perawatan Hutan Kota BNI Tibang dan Taman Kota BNI Trembesi dengan tingkat kolaborasi mencapai tingkatan partnership (kemitraan) antara stakeholder pemerintah dan nonpemerintah.
\end{abstract}

Kata kunci: Peremajaan kota; pembaharuan kota; kota layak huni; ruang terbuka hijau; perencanaan kolaboratif

\begin{abstract}
Green space is an important component of city life that functions to maintain urban ecosystem. The presence of green space is increasingly pressed due to the rapid rate of urbanization in Indonesia which has an impact on the increasing challenge of green space provisioning in urban area. One of the land that can be optimized as green space is degraded or abandoned land that can be caused by various factors, one of which is natural disasters. BNI Tibang City Forest and BNI Trembesi City Park are green open space developed on abandoned land affected by the Tsunami disaster that struck Aceh in 2004. This study aims to examine the collaboration between government and non-government stakeholders in regenerating Tsunami affected land into green space area, consisting of BNI Tibang City Forest and BNI City Park. The result of the study showed that the regeneration of abandoned land into green space area in two study cases area has contributed respectively 6.75 hectares and 2.59 hectares. Besides, the study showed that a number of non-governmental stakeholders consisting of non-governmental organizations (NGOs), the private sector, and the community were involved in the initiation, implementation and maintenance stages of the BNI Tibang City Forest and the BNI Trembesi City Park with the collaboration degree reaching the partnership between government and non-government stakeholders.
\end{abstract}

Keywords: Urban regeneration; urban renewal; livable city; green space; collaborative planning

\section{PENDAHULUAN}

Ruang terbuka hijau (RTH), atau area memanjang/mengelompok tempat tanaman tumbuh, merupakan salah satu komponen penting yang tidak terpisahkan dari kehidupan kota sebagai penyeimbang ekosistem kota yang memiliki peranan baik secara ekologis maupun sosial (Ditjen Penataan Ruang, 2008). Secara ekologis, RTH berperan untuk mengontrol kualitas air dan udara, menyerap karbon, dan mencegah erosi. Di samping itu, RTH juga berperan sebagai sumber daya yang dibutuhkan oleh manusia dan makhluk hidup lainnya untuk dapat bertahan hidup (The Economics of Ecosystems and Biodiversity, 2011). Sumber daya ini dapat berupa air bersih, makanan (tumbuhan, buah-buahan, hewan), serta obat-obatan herbal yang berasal dari tumbuhan.
RTH juga memiliki peranan secara sosial, yaitu sebagai ruang alternatif untuk warga kota berinteraksi, serta tempat bagi warga untuk dapat melakukan kegiatan rekreasi dan wisata (Arnita et al. 2014). Keberadaan RTH secara sosial dapat berkontribusi terhadap peningkatan kesehatan mental dan fisik masyarakat kota, serta lebih jauh lagi dapat meningkatkan kesejahteraan masyarakat kota (The Economics of Ecosystems and Biodiversity, 2011).

Selain itu, RTH merupakan salah satu komponen yang mendukung tercapainya kota layak huni (Ikatan Ahli Perencana, 2017). Kota layak huni merupakan konsep pengembangan kota yang mengedepankan kenyamanan dan kualitas kehidupan warga suatu kota (Ikatan Ahli Perencana, 2017).

Meskipun memiliki peranan yang penting untuk menjaga keseimbangan ekosistem kota, keberadaan RTH 
semakin terdesak akibat dari pesatnya laju urbanisasi di kota-kota Indonesia, yang ditandai dengan meningkatnya proporsi penduduk kawasan perkotaan di Indonesia. Pada tahun 2015, tercatat proporsi jumlah penduduk kawasan perkotaan di Indonesia telah mencapai angka 53,3\% (Badan Pusat Statistik, 2018). Kondisi ini berbanding terbalik dengan kondisi pada tahun 1980 yang pada saat itu hanya $22,4 \%$ penduduk Indonesia tinggal di kawasan perkotaan (Lembaga Ilmu Pengetahuan Indonesia, 2019). Peningkatan ini diperkirakan akan terus terjadi dan menyentuh angka 72,9\% pada tahun 2045 (Badan Pusat Statistik, 2019).

Sebagai dampak dari pesatnya laju urbanisasi, konversi lahan RTH menjadi lahan terbangun menjadi suatu pemandangan yang tidak terhindarkan di berbagai kota di Indonesia. Lahan-lahan yang seharusnya dikonservasi sebagai RTH seperti di area sempadan sungai, waduk, serta pantai, telah beralih fungsi menjadi bangunan liar. Hal ini bertentangan dengan mandat yang tertuang pada Peraturan Menteri Pekerjaan Umum Nomor: 05/PRT/M/2008 Tentang Pedoman Penyediaan dan Pemanfaatan Ruang Terbuka Hijau di Kawasan Perkotaan, bahwa setiap kota di Indonesia wajib menyediakan minimal 20\% dari seluruh luas wilayah kota sebagai RTH publik.

Terganggunya keseimbangan ekosistem kota berdampak terhadap sejumlah permasalahan ekologis dan sosial. Secara ekologis, muncul permasalahan lingkungan seperti polusi dan banjir (The Economics of Ecosystems and Biodiversity, 2011). Secara sosial, berkurangnya RTH menyebabkan semakin langkanya ruang bagi masyarakat untuk berinteraksi dan melakukan aktivitas rekreasi dan wisata (Caesarina dan Rahmani, 2019).

Salah satu lahan yang dapat dioptimalkan dan dimanfaatkan menjadi RTH adalah lahan-lahan yang telah mengalami degradasi fungsi maupun lahan terlantar yang dapat disebabkan oleh berbagai faktor seperti perang, bencana alam, degradasi sektor industri tertentu yang menyebabkan kosongnya bangunan dan kawasan industri (McCarthy, 2007). Dalam ilmu perencanaan kota, optimalisasi lahan yang terdegradasi dikenal dengan berbagai istilah seperti peremajaan kota (urban regeneration), peremajaan kota (urban redevelopment) dan pembaharuan kota (urban renewal).

Bencana gempa yang melanda Aceh pada 26 Desember 2004 merupakan peristiwa bencana gempa bumi terbesar kedua dalam sejarah manusia, dengan magnitude mencapai 9,1 SR, (Mangkusubroto, 2011). Gempa dahsyat ini kemudian diikuti oleh Tsunami yang menghancurkan kota-kota di sejumlah negara seperti Indonesia, Thailand, Sri Lanka, India, hingga Myanmar. Bencana tersebut telah menyebabkan total korban jiwa yang mencapai 127.720 orang serta menghancurkan 139.195 rumah, 3.415 sekolah, dan 517 fasilitas kesehatan (Sugiarto, 2009). Selain itu, Tsunami turut menyebabkan rusaknya lahan-lahan yang disebabkan oleh intrusi air laut dan pencemaran sampah Tsunami (Arnita et al. 2014; Mangkusubroto, 2011)

Di samping itu, Kota Banda Aceh merupakan salah satu kota di Indonesia yang masih dihadapkan pada tantangan dalam penyediaan RTH. Tercatat proporsi RTH publik di Kota Banda Aceh baru mencapai angka 11\%, dengan luas area 688 ha (Arnita et al., 2014). Artinya, masih terdapat kekurangan RTH publik sebesar 9\%, atau seluas 552 ha. Menyikapi hal ini, salah satu langkah yang diambil oleh pemerintah adalah mengembangkan lahan terlantar akibat Tsunami menjadi RTH, sebagaimana yang dilakukan di Hutan Kota BNI Tibang dan Taman Kota BNI Trembesi.

Pengembangan RTH secara kolaboratif merupakan salah satu pendekatan yang dapat didorong untuk menambah proporsi RTH perkotaan. Perencanaan kolaboratif adalah proses perencanaan yang dilakukan melalui diskusi lintas stakeholder (Ansel dan Gash, 2007). Selain itu, perencanaan kolaboratif merupakan pendekatan alternatif dalam penataan ruang yang tidak hanya melibatkan stakeholder pemerintah namun juga stakeholder non-pemerintah dalam perencanaan pembangunan (Van der Jagt et al. 2016). Salah satu dampak positif dari perencanaan kolaboratif adalah output yang dihasilkan menjadi lebih sesuai dengan kebutuhan, serta mengurangi ketergantungan terhadap pemerintah dalam penataan ruang (Nikolaidou et al, 2016).

Pada penelitian ini akan dibahas pengembangan RTH kolaboratif di Kota Banda Aceh, tepatnya di Hutan Kota BNI Tibang dan Taman Kota BNI Trembesi. Pengembangan RTH di kedua lokasi ini tidak hanya melibatkan stakeholder pemerintah, namun juga stakeholder non-pemerintah.

Adapun fokus dari penelitan ini meliputi: (1) mengidentifikasi stakeholder pemerintah dan nonpemerintah yang terlibat dalam pengembangan Hutan Kota BNI Tibang dan Taman Kota BNI Trembesi, dan (2) mengetahui tingkat keterlibatan stakeholder nonpemerintah dalam pengembangan RTH di Hutan Kota BNI Tibang dan Taman Kota BNI Trembesi.

\section{METODE}

Metode yang digunakan dalam penelitian ini adalah metode penelitian deskriptif kualitatif. Adapun pengumpulan data dilakukan melalui teknik wawancara dan pengumpulan data sekunder berupa dokumen perencanaan RTH terkait. Pemilihan narasumber dilakukan dengan menggunakan teknik purposive sampling serta snowball sampling. Pada awal penelitian, sejumlah calon narasumber berasal dari unsur pemerintah khususnya Dinas Kebersihan dan Keindahan Kota Banda Aceh (DK3), pengelola taman, masyarakat, serta lembaga swadaya masyarakat (LSM) yang terlibat dalam pembangunan RTH di lokasi penelitian. Walaupun sudah ditentukan sejak awal, jumlah narasumber yang diwawancarai bertambah sesuai 
dengan rekomendasi yang diberikan dari narasumber kunci yang telah diidentifikasi sebelumnya. Hasil wawancara kemudian disusun menjadi transkrip wawancara, sebelum diolah melalui analisis coding untuk mengidentifikasi kata-kata kunci yang berkaitan dengan fokus penelitian.

Fokus penelitian yang pertama pada penelitian ini adalah mengidentifikasi stakeholder yang terlibat dalam pengembangan Hutan Kota BNI Tibang dan Taman Kota BNI Trembesi. Secara umum, stakeholder terbagi menjadi dua yaitu stakeholder pemerintah dan stakeholder non-pemerintah (Ansel dan Gash, 2007). Stakeholder pemerintah terdiri dari pemerintah tingkat kabupaten/kota, provinsi dan pusat baik yang berbentuk dinas, badan, mahkamah maupun dewan. Sedangkan stakeholder non-pemerintah meliputi individu maupun kelompok yang tidak memiliki keterikatan atau kontrak untuk bekerja dengan pemerintah, yang meliputi pelaku bisnis (enterpreneur), lembaga swadaya masyarakat (LSM), kelompok/komunitas masyarakat, dan individu masyarakat (Nikolaidou et al, 2016).
Fokus kedua dari penelitian ini adalah untuk mengetahui tingkat keterlibatan stakeholder nonpemerintah dalam pengembangan RTH di kedua studi kasus yang dibahas pada penelitian ini. Menurut Van der Jagt et al. (2016), tingkat keterlibatan stakeholder nonpemerintah dalam pengembangan RTH terbagi dalam lima tingkatan, yaitu: (1) inform, (2) consult, (3) involve, (4) partnership dan (5) empower. sebagaimana terlihat pada Tabel 1.

Informasi yang digunakan untuk menjawab kedua fokus penelitian ini didapatkan melalui studi literatur, yaitu dengan mengkaji dokumen perencanaan RTH terkait, serta dokumen profil RTH Kota Banda Aceh. Di samping itu, pengumpulan informasi tersebut juga diperkaya dengan wawancara yang dilakukan dengan narasumber terkait. Melalui wawancara dapat dilakukan verifikasi informasi yang terdapat di dokumen yang telah dikaji, sekaligus menambahkan informasiinformasi yang belum tersedia pada dokumen-dokumen rencana terkait.

Tabel 1. Tingkat Keterlibatan Stakeholder Non-Pemerintah dalam Penyediaan RTH

\begin{tabular}{|c|c|c|}
\hline $\begin{array}{l}\text { Tingkat Keterlibatan } \\
\text { Stakeholder Non-Pemerintah }\end{array}$ & Peran Stakeholder Non-Pemerintah & $\begin{array}{l}\text { Peran Stakeholder } \\
\text { Pemerintah }\end{array}$ \\
\hline 1. Inform & Mendapatkan informasi rencana pengembangan RTH & Dominan \\
\hline 2. Consult & Memberikan masukan terhadap rencana pengembangan RTH & Dominz \\
\hline 3. Involve & $\begin{array}{l}\text { Terlibat dalam pengambilan keputusan, perawatan atau } \\
\text { manajemen RTH }\end{array}$ & \\
\hline 4. Partnership & Pengelolaan RTH bersama dengan pemerintah & Fasilitator \\
\hline 5. Empower & Pengelolaan RTH secara swadaya & \\
\hline
\end{tabular}

*) sumber: Van der Jagt et al., 2016:5

Penelitian ini menggunakan pendekatan multiple case studies (studi kasus ganda), yang berarti menggunakan lebih dari satu studi kasus. Pemilihan metode ini dilakukan untuk memperkaya informasi yang didapatkan untuk menjawab kedua fokus penelitian. Adapun pemilihan studi kasus didasari oleh adanya keterlibatan stakeholder non-pemerintah dalam pengembangan RTH di studi kasus yang dipilih. Studi kasus pada penelitian ini terdiri dari Hutan Kota BNI Tibang dan Taman Kota BNI Trembesi.

\section{Profil Hutan Kota BNI Tibang}

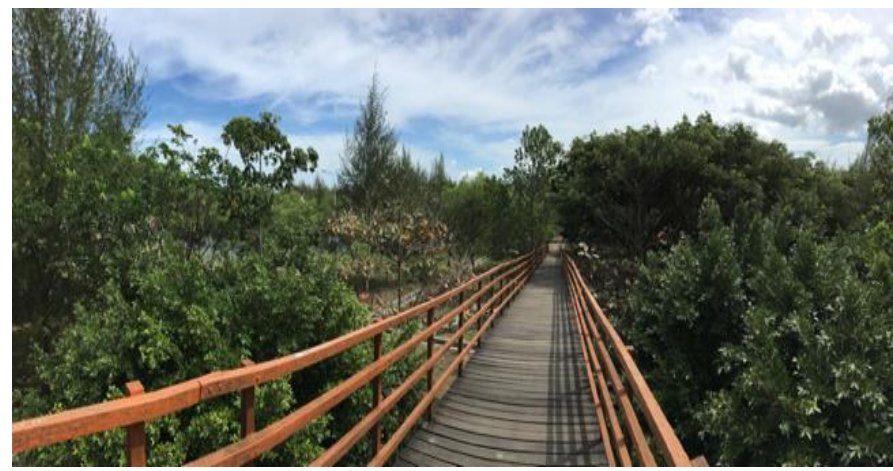

Gambar 1. Hutan Kota BNI Tibang
Didirikan pada tahun 2010, Hutan Kota BNI Tibang terletak di tanah yang terlantar dan tidak produktif disebabkan oleh adanya intrusi air laut setelah peristiwa bencana Tsunami pada tahun 2004. Lokasi RTH ini berdekatan dengan garis pantai, dengan jarak kurang dari satu kilometer, dan merupakan salah satu daerah yang paling terdampak dari bencana Tsunami. Tanah terlantar seluas $6,75 \mathrm{Ha}$ ini kemudian mulai dikonversi menjadi hutan kota, tepatnya pada tahun 2010, dan dinamakan Hutan Kota BNI Tibang (Arnita et al. 2014). Pengembangan Hutan Kota ini memakan waktu selama empat tahun, dan selesai dibangun pada tahun 2014.

Hutan Kota BNI Tibang didominasi oleh beragam vegetasi yang ditanam di seluruh sisinya. Seperti terlihat pada Gambar 2, terdapat taman tematik bambu, tumbuhan aromatik, bunga, serta tanaman herbal di Hutan Kota BNI Tibang (Yayasan Bustanussalatin, 2010). Selain itu, terdapat pula kolam bakau dan pembibitan ikan. Tidak hanya menyediakan ekosistem yang baik untuk flora dan fauna, Hutan Kota BNI Tibang juga menyediakan sarana rekreasi yang dapat digunakan oleh warga untuk berinteraksi dan 
Hafi Munirwan et al, Peremajaan Lahan Terdampak Tsunami Menjadi Ruang Terbuka Hijau Melalui Pendekatan Perencanaan Kolaboratif di Kota Banda Aceh (Studi Kasus Hutan Kota BNI Tibang dan Taman Kota BNI Trembesi)

menghilangkan penat, seperti jalur pejalan kaki, mangrove board walk, ramp canopy trail, serta taman kontemplasi.

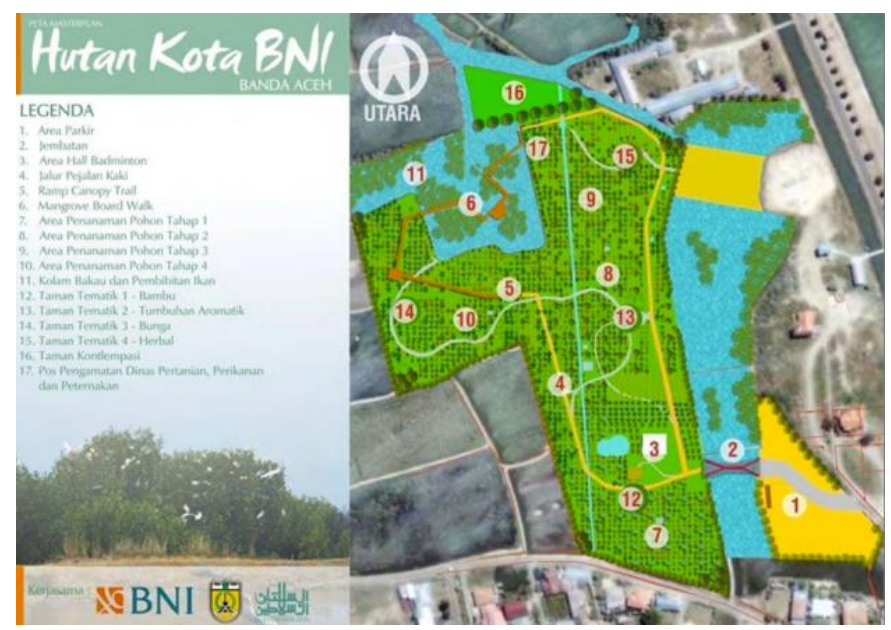

Gambar 2. Masterplan Hutan Kota BNI Tibang

\section{Profil Taman Kota BNI Trembesi}

Didirikan pada tahun 2011, Taman Kota BNI Trembesi memiliki total luas area yang mencapai 2,59 Ha (Arnita et al. 2014). Sebelum dikembangkan sebagai RTH, lahan ini merupakan tanah terlantar yang hancur akibat bencana Tsunami yang menimpa Aceh pada tahun 2004.

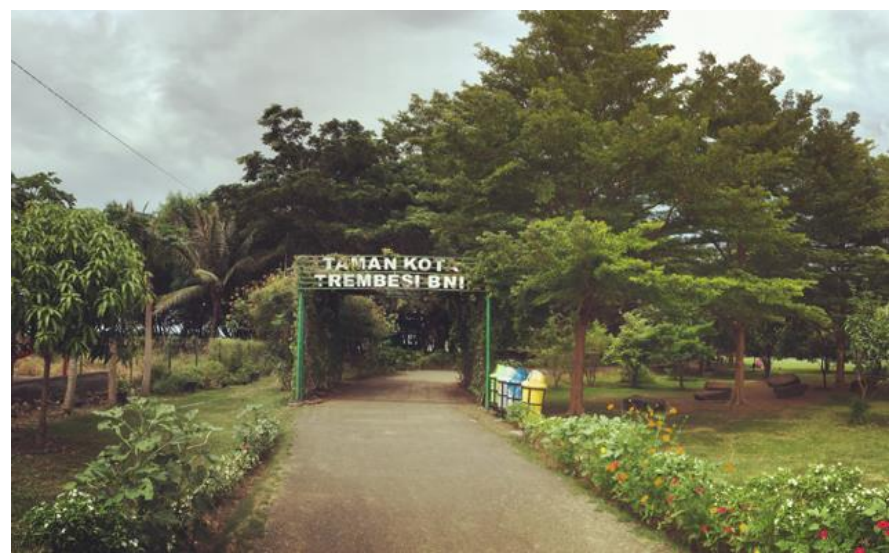

Gambar 3. Taman Kota BNI Trembesi

Nama "Trembesi" disematkan pada taman ini karena pohon Trembesi merupakan spesies vegetasi dominan yang ditanam pada taman ini. Secara keseluruhan, terdapat 204 pohon Trembesi yang ditanam pada taman ini (Arnita, 2014). Meski didominasi oleh pohon Trembesi, taman ini juga dilengkapi dengan sejumlah tanaman buah-buahan, sebagaimana terlihat pada Gambar 4. Sejumlah tanaman buah yang ditanam di antaranya adalah sawo, jambu air, mangga, sukun, nangka, asam, sirsak, kedondong, durian, labu dan melon. Pada taman ini juga terdapat pembibitan tanaman hias yang dijual kepada pengunjung taman. Selain itu, terdapat pula jalur pejalan kaki, plaza, dan gazebo yang dapat digunakan oleh pengunjung untuk bersosialisasi dan beristirahat.

\section{HASIL DAN PEMBAHASAN}

Stakeholder yang Terlibat dalam Penyediaan Hutan Kota BNI Tibang dan Taman Kota BNI Trembesi

Pada tahun 2010, pemerintah Kota Banda Aceh berencana untuk menginisiasi pengembangan hutan kota yang terletak di wilayah Desa Tibang, Kota Banda Aceh. Lahan ini merupakan lahan yang rusak dan terabaikan pasca bencana Tsunami pada tahun 2004. Tsunami yang menerjang wilayah ini menyebabkan lahan ini dipenuhi oleh puing-puing bangunan, sampah sisa Tsunami, serta buruknya kualitas lahan yang mengalami degradasi akibat intrusi air laut.

Pengembangan RTH di lahan seluas $6,75 \mathrm{Ha}$ memerlukan pendanaan yang tidak sedikit, sedangkan anggaran pendapatan belanja daerah (APBD) Kota Banda Aceh pun terbatas. Oleh karena itu, pemerintah Kota Banda Aceh mengajak Yayasan Bustanussalatin, salah satu LSM yang bergerak di pelestarian heritage Aceh, untuk mengembangkan lahan tersebut menjadi hutan kota.

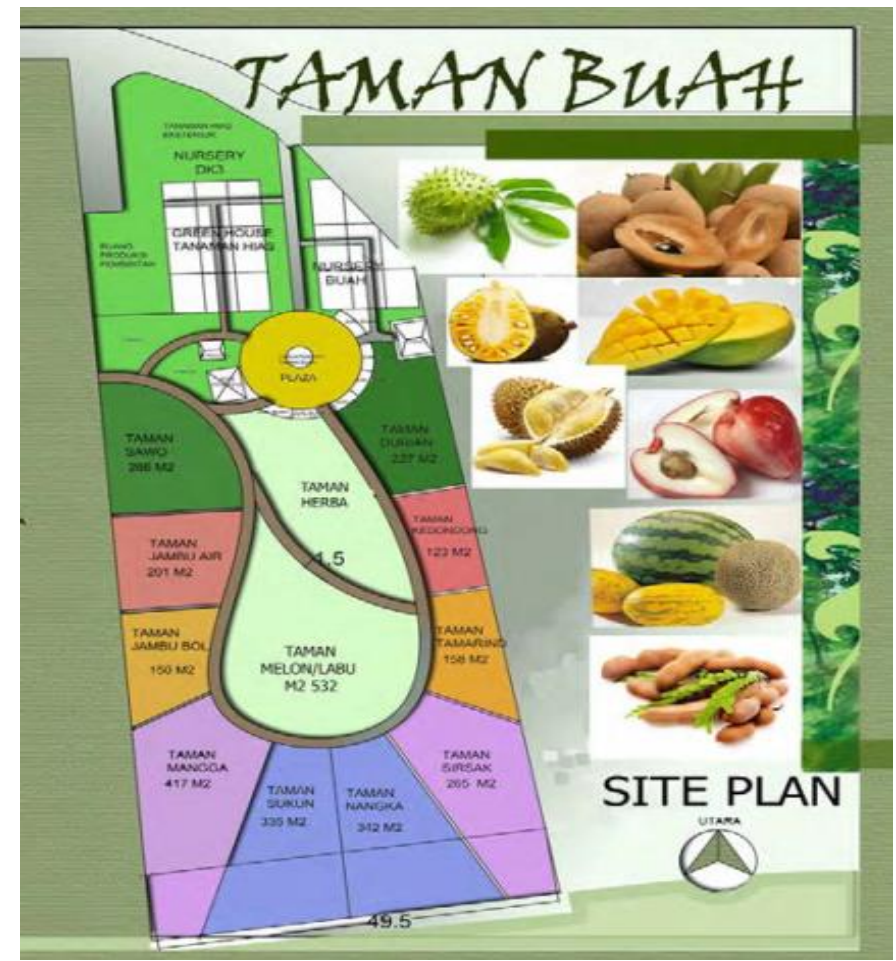

Gambar 4. Masterplan Taman Kota BNI Trembesi

Meskipun bergerak di bidang pelestarian heritage, Yayasan Bustanussalatin juga memiliki tujuan untuk melestarikan tanaman-tanaman lokal khas Aceh yang semakin langka akibat bencana Tsunami. Sehingga, LSM ini kerap turut serta dalam kegiatan penghijauan dan penanaman pohon, terutama penanaman tanaman lokal khas Aceh. Sebelumnya, pada tahun 2008, LSM ini turut serta menginisiasi berdirinya Taman Pembibitan (Nursery Park) Bustanussalatin yang berada di pusat 
Kota Banda Aceh. Pada taman ini dilakukan pembibitan terhadap sejumlah tanaman khas Aceh. Berdasarkan pengalaman bekerjasama dalam pembangunan taman inilah, pemerintah Kota Banda Aceh mengajak Yayasan Bustanussalatin untuk mengembangkan Hutan Kota BNI Tibang. Yayasan Bustanussalatin pun kemudian menyetujui untuk ikut mengembangkan Hutan Kota BNI Tibang.

Peran awal yang dilakukan oleh Yayasan Bustanussalatin adalah menyusun proposal rencana pengembangan Hutan Kota BNI Tibang bersama dengan pemerintah kota, khususnya DK3 sebagai instansi terkait pengelola RTH di Kota Banda Aceh. Proposal pengembangan ini selanjutnya diajukan ke berbagai jaringan (network) yang dimiliki oleh Yayasan Bustanussalatin, salah satunya adalah PT. BNI Persero.

Melalui pengajuan proposal yang dilakukan oleh Yayasan Bustanussalatin, PT. BNI Persero kemudian menyetujui untuk memberikan dana corporate social responsibility (CSR). Hal ini dikarenakan sejak tahun 2008, BNI turut meluncurkan program CSR yang bernama BNI Go Green, yang mendukung program penghijauan di berbagai kota di Indonesia. Dalam hal ini, pengembangan Hutan Kota BNI Tibang akan dilakukan di lahan milik pemerintah Kota Banda Aceh, dengan menggunakan dana CSR dari PT. BNI Persero, serta dibangun melalui pemberdayaan masyarakat yang difasilitasi oleh Yayasan Bustanussalatin.

Pola kerjasama yang serupa kembali dilakukan oleh pemerintah kota Banda Aceh pada tahun 2011, yaitu ketika pemerintah kota mengajak Yayasan Bustanussalatin untuk mengembangkan lahan terlantar milik pemerintah kota yang berada di Desa Peulanggahan menjadi taman kota. Lahan ini memiliki ukuran yang lebih kecil dari Hutan Kota BNI Tibang, yaitu 2,59 Ha. Yayasan Bustanussalatin bersama dengan pemerintah kemudian menyusun proposal rencana pengembangan hutan kota yang kembali diajukan ke PT. BNI Persero. Proposal ini pun kembali disetujui oleh PT. BNI Persero dan dikembangkan melalui skema pendanaan CSR. Untuk mengapresiasi PT. BNI Persero yang telah mendanai pengembangan taman tersebut, taman ini pun kemudian dikenal dengan nama Taman Kota BNI Trembesi.

Proses pembangunan kedua RTH ini melibatkan warga lokal, atau warga gampong yang berada di sekitar lokasi RTH tersebut. Yayasan Bustanussalatin sebagai fasilitator pemberdayaan masyarakat dalam pengembangan RTH di kedua lokasi tersebut berkoordinasi dengan warga sekitar serta pemangku kepentingan di tingkat kecamatan dan gampong.

Warga sekitar yang terlibat dalam pengembangan RTH ini didominasi oleh kalangan ibu-ibu. Terdapat sejumlah 80 ibu-ibu yang terlibat dalam pengerjaan pengembangan RTH, yang meliputi kegiatan persiapan dan pembersihan lahan dari sampah, penanaman vegetasi, serta perawatan RTH. Selain merawat RTH yang telah terbangun, warga juga dapat menghasilkan pendapatan melalui penjualan bibit, tanaman herbal, buah-buahan dan pupuk yang dihasilkan.

Meskipun warga terlibat dalam perawatan Hutan Kota BNI Tibang dan Taman Kota BNI Trembesi, kedua RTH ini secara formal masih tergolong RTH publik. Hal ini dikarenakan lahan kedua RTH ini merupakan milik pemerintah kota Banda Aceh.

\section{Tingkat Keterlibatan Stakeholder Non-Pemerintah dalam Penyediaan Hutan Kota BNI Tibang dan Taman Kota BNI Trembesi}

Berdasarkan hasil analisis stakeholder yang telah dilakukan pada bagian sebelumnya, dapat disimpulkan bahwa pengembangan Hutan Kota BNI Tibang dan Taman Kota BNI Trembesi melibatkan stakeholder pemerintah maupun non-pemerintah.

Keterlibatan stakeholder pemerintah dimulai dari tahapan inisiasi pengembangan RTH. Pemerintah kota sebagai pemilik kedua lahan yang terlantar akibat bencana Tsunami berencana mengembangkan lahan yang terabaikan ini menjadi RTH berupa hutan kota dan taman kota. Adapun pemerintah dalam hal ini terdiri dari pemerintah kota meliputi walikota, wakil walikota dan sekretaris daerah, serta DK3 selaku instansi pengelola RTH di Kota Banda Aceh. Tidak hanya di tahap inisiasi, pemerintah turut terlibat dalam pengembangan rencana, implementasi, serta perawatan RTH. Keterlibatan pemerintah dalam pengembangan RTH ini tentunya tidak terlepas dari status masing-masing lahan RTH yang dimiliki oleh pemerintah kota.

Meskipun memiliki lahan seluas 6,75 dan 2,59 ha, pemerintah kota masih dihadapkan dengan masalah pembiayaan pengembangan RTH di kedua lokasi. Hal ini dikarenakan pemerintah kota memiliki keterbatasan anggaran untuk pengembangan RTH.

Oleh karena itu, pemerintah kemudian mengajak Yayasan Bustanussalatin untuk membantu pengembangan serta membantu mencari sumber pendanaan alternatif untuk pengembangan RTH di kedua lokasi tersebut. Sehingga, keterlibatan stakeholder nonpemerintah, khususnya LSM, sudah dimulai sejak tahapan inisiasi pengembangan, saat LSM membantu menyusun rencana pengembangan dan mencari sumber pendanaan alternatif.

Stakeholder non-pemerintah lain yang terlibat adalah dari pihak swasta, yaitu PT. BNI Persero yang mendanai pengembangan Hutan Kota BNI Tibang dan Taman Kota BNI Trembesi melalui skema pendanaan CSR BNI Go Green. Pada tahap perawatan, warga lokal turut terlibat. Meskipun melibatkan warga lokal, perawatan kedua RTH ini tidak terlepas pula dari peranan pemerintah khususnya DK3. Hal ini dikarenakan status kepemilikan kedua RTH ini berada di tangan pemerintah Kota Banda Aceh.

Berdasarkan elaborasi keterlibatan stakeholder di atas, dapat disimpulkan bahwa tingkat keterlibatan 
stakeholder non-pemerintah dalam pengembangan RTH di kedua studi kasus penelitian ini termasuk pada tingkatan partnership (kemitraan). Tingkatan ini mencerminkan peran stakeholder pemerintah yang tidak dominan, dan terdapat desentralisasi kewenangan yang ditransfer kepada stakeholder non-pemerintah (Van der Jagt et al. 2016). Desentralisasi kewenangan ini terlihat setidaknya dari beberapa hal, di antaranya penyusunan rencana pengembangan yang dilakukan secara bersamasama oleh LSM dan pemerintah, pendanaan pembangunan yang bersumber dari dana swasta, implementasi pengembangan yang melibatkan LSM dan warga lokal, serta keterlibatan warga lokal dalam perawatan RTH. Hal ini mencerminkan kolaborasi yang terjadi antara stakeholder pemerintah dan nonpemerintah.

Tabel 2. Tingkat Keterlibatan Stakeholder Non-Pemerintah Dalam Penyediaan RTH Hutan Kota BNI Tibang dan Taman Kota BNI Trembesi

\begin{tabular}{|c|c|c|}
\hline $\begin{array}{l}\text { Tingkat Keterlibatan } \\
\text { Stakeholder Non-Pemerintah }\end{array}$ & Peran Stakeholder Non-Pemerintah & $\begin{array}{l}\text { Peran Stakeholder } \\
\text { Pemerintah }\end{array}$ \\
\hline 1. Inform & Mendapatkan informasi rencana pengembangan RTH & \\
\hline 2. Consult & Memberikan masukan terhadap rencana pengembangan RTH & \\
\hline 3. Involve & $\begin{array}{l}\text { Terlibat dalam pengambilan keputusan, perawatan atau } \\
\text { manajemen RTH }\end{array}$ & \\
\hline 4. Partnership & Pengelolaan RTH bersama dengan pemerintah & Fasilitator \\
\hline 5. Empower & Pengelolaan RTH secara swadaya & \\
\hline
\end{tabular}

\section{SIMPULAN}

Berdasarkan hasil pembahasan yang telah dijabarkan pada bagian di atas, peneliti menyimpulkan bahwa penyediaan RTH dapat ditingkatkan dengan meremajakan atau meremajakan lahan terlantar maupun lahan yang telah mengalami degradasi fungsi. Sebagaimana telah dibahas, kedua lokasi RTH yang menjadi studi kasus pada penelitian ini telah memberikan kontribusi luasan RTH masing-masing seluas 6,75 Ha dan 2,59 Ha.

Selain itu, penelitian ini juga telah membahas keterlibatan stakeholder pemerintah dan non-pemerintah dalam pengembangan Hutan Kota BNI Tibang dan Taman Kota BNI Trembesi. Stakeholder pemerintah yang terdiri dari pemerintah kota dan DK3 mulai terlibat sejak tahap inisiasi hingga tahap perawatan RTH. Stakeholder non-pemerintah yang terlibat dalam pengembangan kedua RTH ini terdiri dari LSM, swasta, dan masyarakat. LSM terlibat sejak tahap inisiasi hingga tahap implementasi pengembangan, sedangkan pihak swasta terlibat di tahap implementasi pengembangan. Adapun masyarakat terlibat di tahap implementasi dan perawatan RTH.

Hasil pembahasan turut menunjukan tingkat keterlibatan stakeholder non-pemerintah dalam penyediaan RTH di Hutan Kota BNI Tibang dan Taman Kota BNI Trembesi tergolong dalam tingkatan partnership (kemitraan). Hal ini didasari oleh adanya beberapa peran pemerintah yang didesentralisasikan ke stakeholder non-pemerintah, seperti menyusun rencana pengembangan, pendanaan pembangunan serta implementasi pengembangan yang melibatkan LSM, warga lokal, dan swasta.

Lebih lanjut, pendekatan kolaboratif dalam penyediaan RTH di Hutan Kota BNI Tibang dan Taman Kota BNI Trembesi ini dapat menjadi pembelajaran bagi kota-kota di Indonesia yang masih kekurangan proporsi
RTH. Sebagaimana pada studi kasus penelitian ini terdapat beberapa peranan yang dapat didesentralisasikan ke stakeholder non-pemerintah terkait pengembangan RTH.

Meski begitu, terdapat catatan penting yang peneliti temui selama melaksanakan penelitian ini, yaitu ketersediaan lahan merupakan salah satu faktor kunci untuk mendorong penyediaan RTH secara kolaboratif. Kedua studi kasus ini dapat berhasil dikembangkan karena pemerintah kota menyediakan lahan untuk pengembangan RTH.

\section{DAFTAR PUSTAKA}

Ansell, C., dan Gash, A. (2007) Collaborative Governance in Theory and Practice. Journal of Public Administration.

Arnita et al. (2014) Profil Taman Kota Banda Aceh 2014. Dinas Kebersihan dan Keindahan Kota Banda Aceh.

Caesarina, H. M., dan Rahmani, D. R. (2019) Penyediaan Ruang Terbuka Hijau dengan Pendekatan Kota Hijau di Perkotaan Martapura. Jurnal Planoearth, 4, 11-17.

Badan Pusat Statistik (2018) Proyeksi Penduduk Indonesia 2015-2045: Hasil SUPAS 2015.

Direktorat Jenderal Penataan Ruang (2008) Peraturan Menteri Pekerjaan Umum No. 05/PRT/M/2008 Tentang Pedoman Penyediaan dan Pemanfaatan Ruang Terbuka Hijau di Kawasan Perkotaan.

Ikatan Ahli Perencana (2017) Indonesia Most Livable City Index.

Lembaga Ilmu Pengetahuan Indonesia (2019) Dinamika Pertumbuhan Penduduk Kota-Kota di Indonesia.

Mangkusubroto, K. (2011) Analisis Dinamika Kolaborasi antara Badan Rehabilitasi dan Rekonstruksi Aceh dan Nias (BRR) dengan Lembaga Donor Pasca Tsunami 2004 
Hafi Munirwan et al, Peremajaan Lahan Terdampak Tsunami Menjadi Ruang Terbuka Hijau Melalui Pendekatan Perencanaan Kolaboratif di Kota Banda Aceh (Studi Kasus Hutan Kota BNI Tibang dan Taman Kota BNI Trembesi)

menggunakan Drama Theory. Manajemen Teknologi, 10(1).

McCarthy (2007) Partnership, Collaborative Planning and Urban Regeneration. Ashgate Publishing, Hampshire, England.

Nikolaidou, S. et al. (2016) Urban Gardening and Green Space Governance: Towards New Collaborative Planning Practices. Urban Planning, 1, 5-19.

Sugiarto, R. (2009). Story: Feat of the Daunting Launch. Banda aceh: Badan Rehabilitasi dan Rekonstruksi NAD-Nias.

The Economics of Ecosystems and Biodiversity (2011) TEEB Manual for Cities: Ecosystem Services in Urban Management.

Van der Jagt et al. (2016) Participatory Governance of Urban Green Spaces: Trends and Practices in the EU. Nordic Journal of Architectural Reserch, 3, 11-40.

Yayasan Bustanussalatin (2010) Laporan Akhir Pembangunan Hutan Kota BNI Tahap 1. 